\title{
Effect of a single dose of montelukast sodium on methacholine chloride $\mathrm{PC}_{20}$
}

\author{
Beth E Davis BSc, Donald W Cockcroft MD FRCPC
}

\begin{abstract}
BE Davis, DW Cockcroft. Effect of a single dose of montelukast sodium on methacholine chloride $\mathrm{PC}_{20^{*}}$ Can Respir J 2005;12(1):26-28.
\end{abstract}

BACKGROUND: It is currently recommended that leukotriene modifiers (receptor antagonists and synthesis inhibitors) be withheld for a minimum of $24 \mathrm{~h}$ before direct bronchoprovocation testing, but there is little evidence to support this recommendation.

OBJECTIVE: To examine the effect of a single oral dose of montelukast sodium $10 \mathrm{mg}$ on airway response to methacholine chlorideinduced bronchoconstriction.

METHODS: A double-blind, placebo-controlled, randomized crossover trial was performed in 12 subjects with asthma whose methacholine chloride concentration causing a $20 \%$ decrease in the forced expiratory volume during the first second of exhalation $\left(\mathrm{PC}_{20}\right)$ was $8 \mathrm{mg} / \mathrm{mL}$ or lower and a baseline forced expiratory volume during the first second of exhalation of $70 \%$ predicted or greater. Twominute tidal breathing methacholine chloride inhalation challenges were performed $1 \mathrm{~h}$ and $25 \mathrm{~h}$ after both $10 \mathrm{mg}$ montelukast sodium and identical-appearing placebo.

RESULTS: There were no significant differences in the methacholine chloride $\mathrm{PC}_{20}$ between active treatment and placebo at $1 \mathrm{~h}$ post $-10 \mathrm{mg}$ montelukast sodium $(1.0 \mathrm{mg} / \mathrm{mL}$ versus $1.3 \mathrm{mg} / \mathrm{mL} ; \mathrm{n}=12$; $\mathrm{P}=0.17$, respectively) or at $25 \mathrm{~h}$ post $-10 \mathrm{mg}$ montelukast sodium ( $1.4 \mathrm{mg} / \mathrm{mL}$ versus $1.9 \mathrm{mg} / \mathrm{mL} ; \mathrm{n}=11 ; \mathrm{P}=0.15$, respectively).

CONCLUSION: A single dose of montelukast sodium did not affect methacholine chloride-induced bronchoconstriction measured after $1 \mathrm{~h}$ and $25 \mathrm{~h}$.

Key Words: Bronchoprotection; Leukotriene receptor antagonist; Methacholine chloride; Montelukast sodium

\section{Effet d'une simple dose de montélukast sodique sur la réaction au chlorure de métha- choline $\mathrm{PC}_{20}$}

HISTORIQUE : On recommande actuellement de s'abstenir d'administrer des modificateurs des leucotriènes (antagonistes de leurs récepteurs et inhibiteurs de leur synthèse) pendant au moins 24 heures avant un test de bronchoprovocation direct, mais les preuves du bien-fondé de cette mesure sont minces.

OBJECTIFS : Mesurer l'effet d'une seule dose orale de $10 \mathrm{mg}$ de montélukast sodique sur la réactivité bronchique au test de bronchoconstriction provoquée par le chlorure de méthacholine

MÉTHODES : Un essai randomisé, à double insu, contrôlé par placebo, avec permutation des groupes a été effectué auprès de 12 patients asthmatiques dont la concentration de chlorure de méthacholine causant une baisse de $20 \%$ du VEMS $\left(\mathrm{PC}_{20}\right.$ ) était de $8 \mathrm{mg} / \mathrm{mL}$ ou moins et qui avaient un VEMS de départ de $70 \%$ ou plus de la valeur prévue durant la première seconde d'expiration. Les tests de mesure du volume courant sur deux minutes après inhalation de chlorure de méthacholine ont été effectués une heure, puis 25 heures après l'administration de $10 \mathrm{mg}$ de montélukast sodique et d'un placebo de même apparence.

RÉSULTATS : La réaction au chlorure de méthacholine $\mathrm{PC}_{20}$ n'a pas été significativement différente selon que les sujets avaient reçu le traitement actif ou le placebo une heure, puis 25 heures après l'administration des $10 \mathrm{mg}$ de montélukast sodique : $1,0 \mathrm{mg} / \mathrm{mL}$ versus $1,3 \mathrm{mg} / \mathrm{mL} ; \mathrm{n}=12$; $\mathrm{P}=0,17$, respectivement; $1,4 \mathrm{mg} / \mathrm{mL}$ versus $1,9 \mathrm{mg} / \mathrm{mL} ; \mathrm{n}=11 ; \mathrm{P}=0,15$, respectivement.

CONCLUSIONS : Une dose simple de montélukast sodique n'a pas affecté le degré de bronchoconstriction provoqué par le chlorure de méthacholine mesuré après une heure et après 25 heures.
$\mathrm{B}$ ronchoprovocation with direct stimuli (eg, methacholine chloride) is frequently used by clinicians to aid in the diagnosis of asthma and by researchers to determine the pharmacological efficacy of existing and novel therapies. The interpretation of the response to methacholine chloride inhalation can only be accurate if agents affecting airway smooth muscle contraction are withheld for the appropriate duration or dosed consistently as necessary. Usually, medications that are known to alter airway responsiveness are withheld for their duration of action before bronchoprovocation. For functional antagonists, such as salbutamol sulfate and formoterol fumarate dihydrate, and specific antagonists, such as ipratropium bromide and tiotropium bromide, this can range from $8 \mathrm{~h}$ to $48 \mathrm{~h}$. Anti-inflammatory therapies (eg, fluticasone proprionate and budesonide) are the least confounding to direct challenge, and can be maintained if dosing has been stable for at least four weeks. Current American Thoracic Society guidelines recommend all leukotriene modifiers be withheld for a minimum of $24 \mathrm{~h}(1)$, but this is not well documented. Because montelukast sodium is a widely prescribed therapy and may be in use when bronchoprovocation testing is indicated, we investigated the effects of a single dose of montelukast sodium on methacholine chloride-induced bronchoconstriction.

\section{Study design}

\section{METHODS}

A double-blind, placebo-controlled study with two randomized identical treatment arms was conducted, consisting of baseline spirometry, administration of a single dose montelukast sodium or identical-appearing placebo, a $1 \mathrm{~h}$ post-dose methacholine 
TABLE 1

Patient demographics

\begin{tabular}{lcccccc}
\hline Subject & Sex & $\begin{array}{c}\text { Age } \\
\text { (years) }\end{array}$ & $\begin{array}{c}\text { Height } \\
\text { (cm) }\end{array}$ & $\begin{array}{c}\text { Baseline } \\
\text { FEV }_{\mathbf{1}}(\mathbf{L})\end{array}$ & $\begin{array}{c}\text { FEV }_{\mathbf{1}} \\
\text { (\% predicted) }\end{array}$ & Medications \\
\hline 1 & $\mathrm{M}$ & 57 & 168 & 2.40 & 71 & $\mathrm{~S}$ \\
2 & $\mathrm{M}$ & 27 & 180 & 3.58 & 78 & $\mathrm{~S}$ \\
3 & $\mathrm{~F}$ & 24 & 157 & 2.54 & 79 & $\mathrm{~S}$ \\
4 & $\mathrm{~F}$ & 23 & 168 & 2.95 & 83 & $\mathrm{~S}$ \\
5 & $\mathrm{M}$ & 25 & 183 & 3.98 & 83 & $\mathrm{~S}$ \\
6 & $\mathrm{~F}$ & 42 & 163 & 3.10 & 106 & $\mathrm{BDP} ; \mathrm{S}$ \\
7 & $\mathrm{~F}$ & 22 & 175 & 3.63 & 94 & $\mathrm{Fl} ; \mathrm{S}$ \\
8 & $\mathrm{~F}$ & 39 & 168 & 2.78 & 88 & $\mathrm{~S}$ \\
9 & $\mathrm{M}$ & 21 & 185 & 3.69 & 74 & $\mathrm{Fl} ; \mathrm{T}$ \\
10 & $\mathrm{~F}$ & 21 & 165 & 3.07 & 87 & $\mathrm{~S}$ \\
11 & $\mathrm{M}$ & 24 & 183 & 4.43 & 109 & $\mathrm{Fl} ; \mathrm{S}$ \\
12 & $\mathrm{~F}$ & 23 & 168 & 3.27 & 91 & $\mathrm{Fl} ; \mathrm{S}$ \\
\hline
\end{tabular}

BDP Beclomethasone diproprionate; F Female; Fl Fluticasone proprionate; FEV 1 Forced expiratory volume during the first second of exhalation; M Male; S Salbutamol sulfate; $T$ Terbutaline sulfate

chloride challenge and a $25 \mathrm{~h}$ post-dose methacholine chloride challenge. Subjects began each methacholine chloride challenge at the same time of day $( \pm 1 \mathrm{~h})$ and the same concentration. The washout between treatments was at least seven days and no more than 10 days. The primary end point was methacholine chloride $\mathrm{PC}_{20}$ (the concentration of methacholine chloride that caused a $20 \%$ decrease in the forced expiratory volume during the first second of exhalation $\left.\left[\mathrm{FEV}_{1}\right]\right)$. Secondary end points included bronchodilation (absolute change in $\mathrm{FEV}_{1}$ ) and adverse event/safety recording.

\section{Subjects}

Twelve individuals with a diagnosis of asthma, positive methacholine chloride $\mathrm{PC}_{20}(\mathrm{eg}, 8 \mathrm{mg} / \mathrm{mL}$ or less $)$ and baseline $\mathrm{FEV}_{1}$ $70 \%$ predicted or greater were enrolled (Table 1). All subjects were of legal age and otherwise healthy. Signed, informed consent to voluntarily participate was obtained before the conduct of any study procedures. Approval to conduct the study was granted by the University of Saskatchewan Ethics Review Board (Saskatoon, Saskatchewan).

\section{Concomitant medications}

Stable doses of inhaled glucocorticosteroids $(n=5)$ initiated at least four weeks before enrollment were allowed to continue at the same dose. Inhaled beta 2 -agonists were withheld for at least $8 \mathrm{~h}$; phosphodiesterase inhibitors, long-acting beta-agonists, leukotriene receptor antagonists and leukotriene enzyme inhibitors were not allowed. Per subject dietary methyl xanthine consumption remained constant throughout the study.

\section{Methacholine chloride challenge}

Methacholine chloride challenge (tidal breathing) was conducted as outlined previously (2). Subjects attended the laboratory and performed three full baseline spirometric manoeuvres followed by oral administration of a single dose of medication. One hour later, spirometry was repeated followed by a methacholine chloride inhalation challenge. Subjects began with diluent inhalation (2 min tidal breathing), and performed truncated spirometry

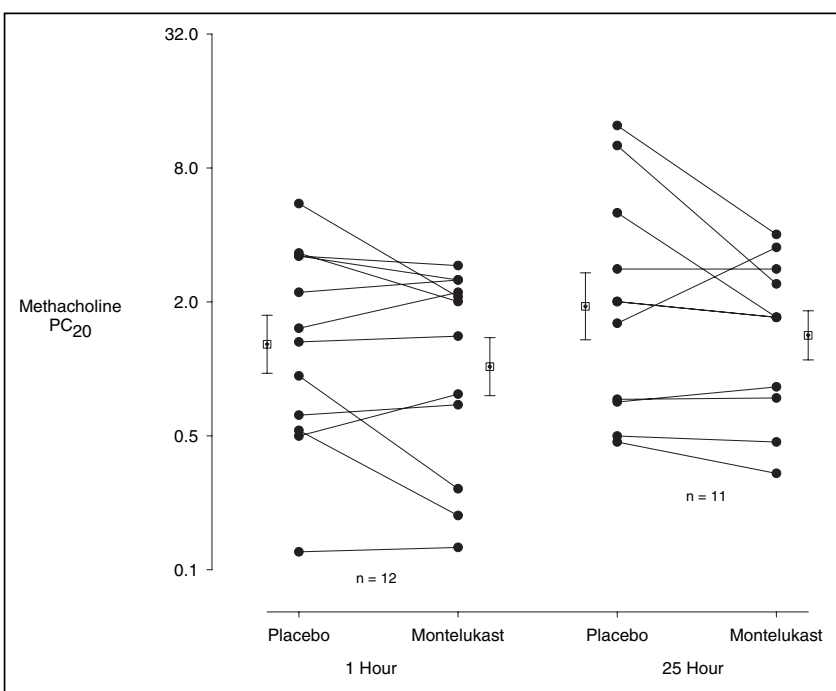

Figure 1) Individual methacholine $\mathrm{PC}_{20}$ (concentration of methacholine chloride that caused a $20 \%$ decrease in forced expiratory volume during the first second of exhalation) data points for each treatment at $1 \mathrm{~h}$ and $25 \mathrm{~h}$. Mean \pm SEM are also shown

manoeuvres to obtain $\mathrm{FEV}_{1}$ values $30 \mathrm{~s}$ and $90 \mathrm{~s}$ postinhalation. The administration of doubling concentrations of methacholine chloride $(0.03 \mathrm{mg} / \mathrm{mL}$ to $8.0 \mathrm{mg} / \mathrm{mL})$ began $5 \mathrm{~min}$ after the start of diluent inhalation. $\mathrm{FEV}_{1}$ was again recorded $30 \mathrm{~s}$ and 90 s postmethacholine chloride inhalation. The same pattern of inhalation (beginning every $5 \mathrm{~min})$ and spirometry $\left(\mathrm{FEV}_{1}\right.$ manoeuvres $30 \mathrm{~s}$ and $90 \mathrm{~s}$ postinhalation) was repeated until the methacholine chloride $\mathrm{PC}_{20}$ could be calculated by interpolation (3) or extrapolation (4). Bennett Twin jet nebulizers (Puritan-Bennett Corporation, USA), calibrated to deliver $0.13 \mathrm{~mL} / \mathrm{min}$, were used to generate aerosols via a loose fitting face mask. The same nebulizer was used for the four challenges within a given subject.

\section{Data analysis}

Methacholine chloride $\mathrm{PC}_{20}$ values were log transformed before paired Student's $t$ test analysis using a computerized statistical program (Statistix for Windows; Analytical Software, USA). Absolute mean $\mathrm{FEV}_{1}$ comparisons were analyzed similarly. A sample size of 12 was adequately powered (greater than 95\%) to detect a 0.5 concentration change in methacholine chloride $\mathrm{PC}_{20}$.

Adverse events/safety

\section{RESULTS}

All subjects completed the study without adverse effects. There was, however, one subject who could not complete one of the four challenges due to inadvertent second-hand methacholine chloride exposure before his scheduled test. After study completion and treatment unblinding, the uncollected data were determined to have occurred during placebo treatment (ie, $25 \mathrm{~h}$ placebo methacholine chloride challenge was not completed).

Methacholine chloride $\mathrm{PC}_{20}$

Geometric mean methacholine chloride $\mathrm{PC}_{20}$ values at $1 \mathrm{~h}$ $(1.0 \mathrm{mg} / \mathrm{mL} ; 95 \%$ CI 0.94 to 1.98$)$ and $25 \mathrm{~h}(1.4 \mathrm{mg} / \mathrm{mL}$; $95 \%$ CI 0.82 to 2.45 ) following active treatment were not significantly different than geometric mean methacholine chloride $\mathrm{PC}_{20}$ values at $1 \mathrm{~h}(1.3 \mathrm{mg} / \mathrm{mL} ; 95 \% \mathrm{CI} 0.66$ to 2.47$)$ and $25 \mathrm{~h}$ $(1.9 \mathrm{mg} / \mathrm{mL} ; 95 \%$ CI 0.90 to 4.13 ) following placebo (Figure 1). 


\section{Bronchodilation (secondary end point)}

Mean $\mathrm{FEV}_{1}$ data also did not differ significantly between the placebo treatment and active treatment. Mean $( \pm$ SEM) for baseline $\mathrm{FEV}_{1}$ values were $3.28 \pm 0.17 \mathrm{~L}$ for active treatment and $3.28 \pm 0.18 \mathrm{~L}$ for placebo treatment $(\mathrm{P}=0.95)$. Mean $1 \mathrm{~h} \mathrm{FEV}$ values were $3.28 \pm 0.16 \mathrm{~L}$ and $3.33 \pm 0.15 \mathrm{~L}$ for active and placebo treatments, respectively $(\mathrm{P}=0.41)$; and mean $25 \mathrm{~h} \mathrm{FEV}_{1}$ values were $3.30 \pm 0.16 \mathrm{~L}$ following active treatment and $3.27 \pm 0.19 \mathrm{~L}$ following placebo $(n=11 ; P=0.62)$.

\section{DISCUSSION}

There is no evidence from our current data that would suggest that a single dose of montelukast sodium influenced airway responsiveness to methacholine chloride for up to $24 \mathrm{~h}$ in mild to moderate, well-controlled atopic asthmatics.

Our findings contradict recently published data (5) which indicated that a single dose of zafirlukast inhibited bronchoconstriction induced by both methacholine chloride and ultrasonically nebulized distilled water. Differences in methodology, such as single-blind versus double-blind design, post-dose timing of the bronchoprovocation challenge ( $2 \mathrm{~h}$ versus $1 \mathrm{~h}$ ), challenge method (dosimeter versus tidal breathing) and patient characteristics (atopic versus nonatopic), are possible explanations.

However, regular dose montelukast sodium $(10 \mathrm{mg} / \mathrm{day}$ for four weeks) has demonstrated bronchoprotective effects against both methacholine chloride and adenosine monophosphate (eg, increased $\mathrm{PD}_{20}$ and $\mathrm{PC}_{20}$, respectively) (6), which is similar to the bronchoprotection afforded by inhaled corticosteroids on allergen-induced airway hyper-responsiveness following oneweek therapy (7) or in nonsteroid-dependent asthmatics following long-term (12 months) therapy (8). Pranlukast administered for four weeks (450 mg/day) has also been shown to increase methacholine chloride $\mathrm{PC}_{20}$ in individuals with acetylsalicylic acid-intolerant asthma who were concomitantly controlled with either inhaled or oral corticosteroids (9). Zafirlukast (20 mg

\section{REFERENCES}

1. Crapo RO, Casaburi R, Coates AL, et al. Guidelines for methacholine and exercise challenge testing - 1999. Am J Respir Crit Care Med 2000;161:309-29.

2. Cockcroft DW, Killian DN, Mellon JJA, Hargreave FE. Bronchial reactivity to inhaled histamine: A method and clinical survey. Clin Allergy 1977;7:235-43.

3. Cockcroft DW, Murdock KY, Mink JT. Determination of histamine $\mathrm{PC}_{20}$. Comparison of linear and logarithmic interpolation. Chest 1983;84:505-6.

4. Jokic R, Davis EE, Cockcroft DW. Methacholine $\mathrm{PC}_{20}$ extrapolation. Chest 1998;114:1796-7.

5. Carratu P, Morelli N, Freire AX, et al. Effect of zafirlukast on methacholine and ultrasonically nebulized distilled water challenge in patients with asthma. Respiration 2003;70:249-53.

6. Dempsey OJ, Kennedy G, Lipworth BJ. Comparative efficacy and anti-inflammatory profile of once-daily therapy with leukotriene antagonist or low-dose inhaled corticosteroid in patients with mild persistent asthma. J Allergy Clin Immunol 2002;109:68-74.

7. Swystun VA, Bhagat R, Kalra S, Jennings B, Cockcroft DW. Comparison of 3 different doses of budesonide and placebo on the early asthmatic response to inhaled allergen. J Allergy Clin Immunol 1998;102:363-7. twice daily for eight weeks) has been shown to improve methacholine chloride $\mathrm{PC}_{20}$ in individuals with mild persistent asthma (10). These studies indicate that all the currently available leukotriene receptor antagonists are capable of decreasing airway responsiveness to direct acting stimuli following a minimum of four weeks of regular dosing. The similarity of this effect to that of inhaled corticosteroids suggests that the mechanism by which these agents act is, at least partly, antiinflammatory in nature (11). As such, withholding montelukast sodium therapy before bronchoprovocation testing in individuals who have established a stable once-a-day dosing regimen (eg, altering the control of the underlying inflammation) may influence airway responsiveness to inhaled methacholine chloride. The present study was designed to investigate the acute effects of a single dose of montelukast sodium on airway responsiveness to methacholine chloride, and, therefore, does not address this issue. Data evaluating the effect of treatment withdrawal on airway responsiveness to methacholine chloride following chronic dosing would be interesting.

The absence of acute antagonism to direct muscarinicinduced bronchoconstriction does not correspond to and should not be interpreted as a lack of clinical efficacy. Recently reviewed data support the clinical benefits of montelukast sodium specifically (12), and of leukotriene modifiers in general $(13,14)$.

\section{CONCLUSIONS}

Montelukast sodium need not be withheld before direct challenge investigations with methacholine chloride as currently recommended, and instead, should perhaps be given the same consideration as inhaled steroids (eg, regular dose for at least four weeks).

FUNDING: This study was supported by a 'medical school grant' from Merck Frosst Canada.

8. Juniper EF, Kline PA, Vanzieleghem MA, Ramsdale EH, O'Byrne PM, Hargreave FE. Effect of long-term treatment with an inhaled corticosteroid (budesonide) on airway hyperresponsiveness and clinical asthma in nonsteroid-dependent asthmatics. Am Rev Respir Dis 1990;142:832-6.

9. Ishioka S, Hozawa S, Haruta Y, et al. Effects of pranlukast, a cysteinyl leukotriene antagonist, on bronchial responsiveness to methacholine in aspirin-intolerant asthmatics treated with corticosteroids. Hiroshima J Med Sci 2000;49:105-8.

10. Riccioni G, Castronuovo M, De Benedictis M, et al. Zafirlukast versus budesonide on bronchial reactivity in subjects with mild-persistent asthma. Int J Immunopathol Pharmacol 2001;14:87-92.

11. Pizzichini E, Leff JA, Reiss TF, et al. Montelukast reduces airway eosinophilic inflammation in asthma: A randomized, controlled trial. Eur Respir J 1999;14:12-8.

12. Blake KV. Montelukast: Data from clinical trials in the management of asthma. Ann Pharmacother 1999;33:1299-314. Erratum in: 2000;34:541

13. Drazen JM, Israel E, O’Byrne PM. Treatment of asthma with drugs modifying the leukotriene pathway. $\mathrm{N}$ Engl J Med 1999;340:197-206. Erratum in: 1999;340:663 and 1999;341:1632.

14. Garcia-Marcos L, Schuster A. Antileukotrienes in asthma: Present situation. Expert Opin Pharmacother 2001;2:441-66. 


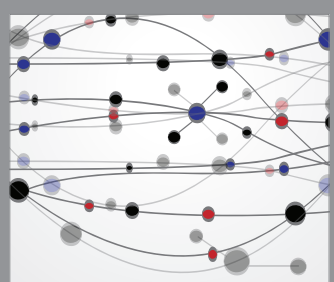

The Scientific World Journal
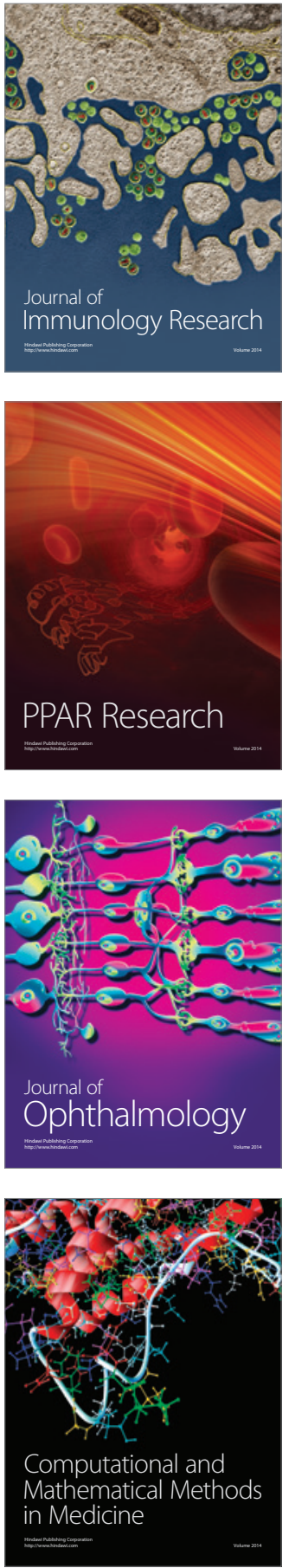

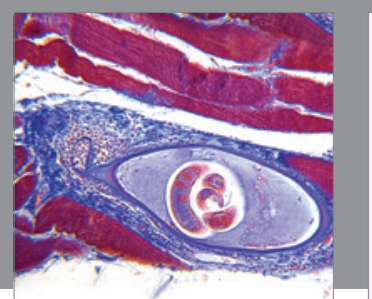

Gastroenterology Research and Practice

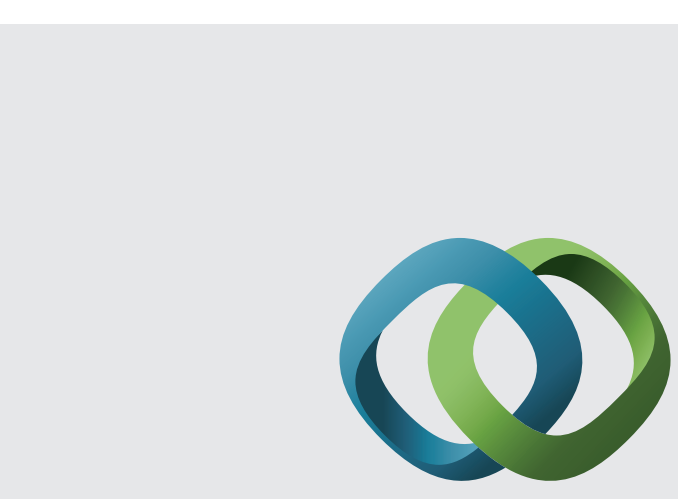

\section{Hindawi}

Submit your manuscripts at

http://www.hindawi.com
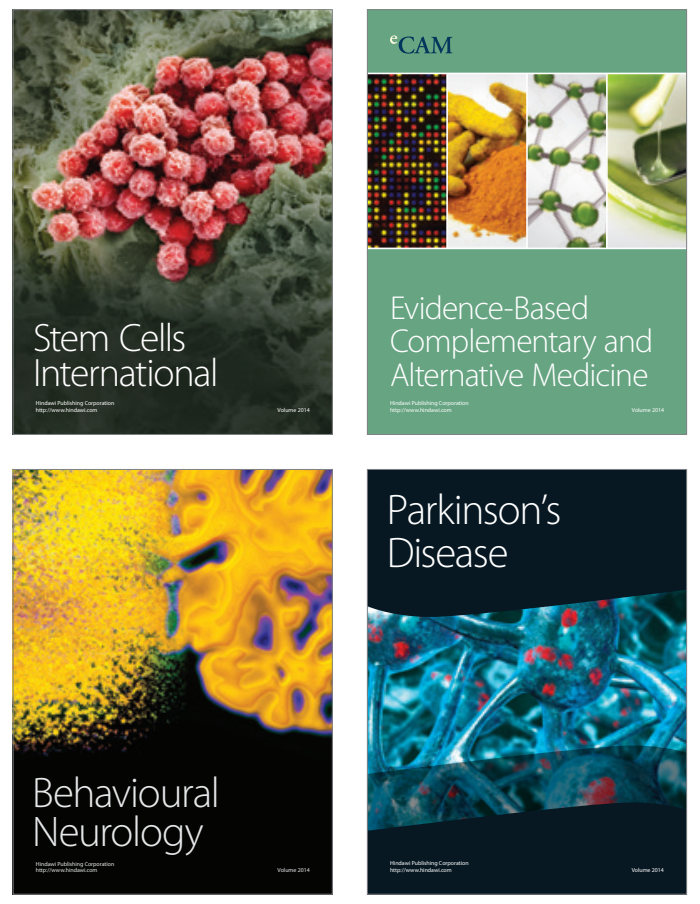
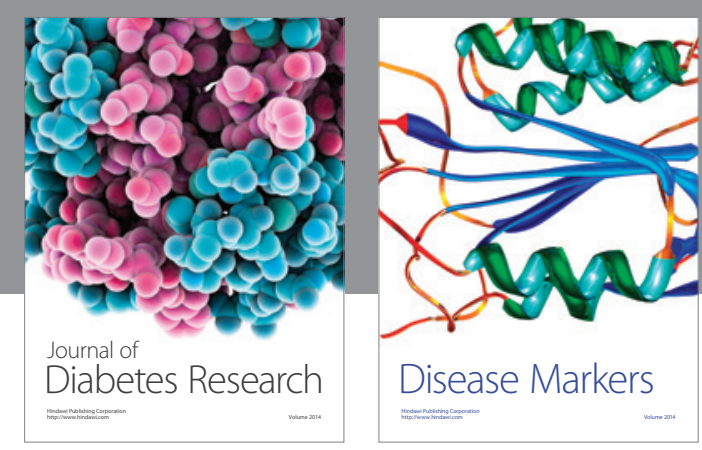

Disease Markers
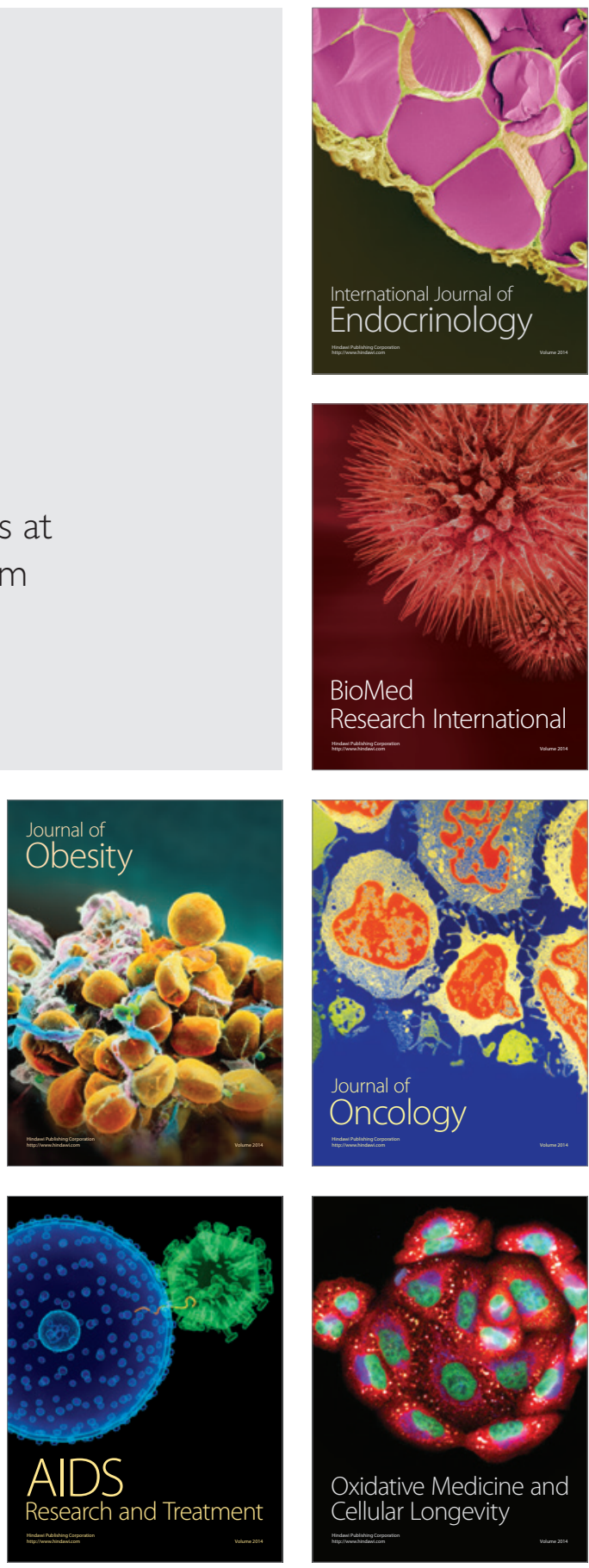